\title{
Perbedaan Aktivitas Antioksidan Kecambah Beras Coklat (Oryza sativa L.) Berdasarkan Lama Proses Elisitasi dan Waktu Perkecambahan
}

\author{
Jaya Mahar Maligan ${ }^{1 *}$, Monica Lestary ${ }^{2}$, Yudi Arimba Wani \\ ${ }^{1}$ Jurusan Teknologi Hasil Pertanian FTP Universitas Brawijaya Malang \\ ${ }^{2}$ Program Studi Ilmu Gizi FK Universitas Brawijaya Malang \\ *Alamat korespondensi : maharajay@gmail.com
}

\begin{abstract}
ABSTRAK
Antioksidan adalah zat yang dapat menangkal radikal bebas. Salah satu cara meningkatkan aktivitas antioksidan adalah dengan elisitasi dan perkecambahan. Penelitian ini bertujuan untuk mengetahui aktivitas antioksidan kecambah beras coklat berdasarkan lama elisitasi dan perkecambahan. Penelitian ini menggunakan studi eksperimental dengan Rancangan Acak Kelompok (RAK) dengan dua faktor yaitu lama elisitasi dan lama perkecambahan, terdiri dari enam kelompok perlakuan yaitu 12 jam elisitasi 24 jam perkecambahan, 18 jam elisitasi 24 jam perkecambahan, 24 jam elisitasi 24 jam perkecambahan, 12 jam elisitasi 36 jam perkecambahan, 18 jam elisitasi 36 jam perkecambahan, dan 24 jam elisitasi 36 jam perkecambahan yang diulang sebanyak tiga kali. Sampel yang digunakan adalah beras coklat varietas mentik. Uji aktivitas antioksidan menggunakan metode DPPH (1,1-Diphenyl-pycryl-hydracil). Hasil penelitian menunjukkan bahwa terdapat perbedaan aktivitas antioksidan kecambah beras coklat berdasarkan lama elisitasi dan perkecambahan pada semua perlakuan dengan nilai $p=0,029$ (Anova, $p<0,05$ ). Perbedaan signifikan pada perlakuan 18 jam elisitasi 24 jam perkecambahan, 24 jam elisitasi 24 jam perkecambahan dengan perlakuan terbaik 24 jam elisitasi 24 jam perkecambahan sebesar $15,91 \%$ Kesimpulan penelitian ini adalah terdapat perbedaan aktivitas antioksidan kecambah beras coklat berdasarkan lama elisitasi dan perkecambahan. Berdasarkan hasil penelitian, disarankan kepada masyarakat untuk mengonsumsi kecambah beras coklat sebagai bahan pangan mengandung antioksidan.
\end{abstract}

Kata Kunci: Aktivitas Antioksidan, Kecambah Beras Coklat, Elisitasi, Kitosan, Perkecambahan

\begin{abstract}
Antioxidants are substances that can counteract free radicals. One way to improve antioxidant activity is the elicitation and germination. This study aims to determine the antioxidant activity of brown rice sprouts based on the length of the elicitation and germination. This study uses an experimental study with a randomized block design (RAK) composed by two factors, elicitation and germination time which consists of six treatments: 12 hours of elicitation 24 hours of germination, 18 hours of elicitation 24 hours of germination, 24 hours elicitation 24 hours of germination, 12 hour elicitation germination 36 hours, 18 hours elicitation germination 36 hours, and 24 hours of elicitation 36 hours of germination were repeated three times. The samples used were Mentik variety brown rice. The antioxidant activity test of this research is the method of DPPH (1,1-
\end{abstract}


Diphenyl-pycryl-hydracil). The results showed that there are differences in antioxidant activity of germinated brown rice based on the length of elicitation and germination in all treatments with $p=0.029$ (ANOVA, $p<0.05$ ). There are significant differences in treatment 18 hours of elicitation 24 hours of germination and 24 hours elicitation 24 hours of germination with the best treatment that is 24 hours elicitation 24 hours of germination with the antioxidant activity of $15.91 \%$. It is concluded that there is a difference in the antioxidant activity of germinated brown rice based on the length of elicitation and germination. Based on the research results, it is suggested to the public to consume germinated brown rice as foodstuffs containing antioxidants

Keywords: Antioxidant Activity, Germinated Brown Rice, Elicitation, Chitosan, Germination

\section{PENDAHULUAN}

Semakin berkembangnya zaman, semakin banyak pembangunan industri yang dapat meningkatkan pencemaran lingkungan dan berdampak buruk pada kesehatan yang disebabkan oleh radikal bebas [1]. Pada dasarnya tubuh mampu melawan radikal bebas, namun jika jumlahnya berlebihan, tubuh tidak mampu menghancurkannya secara sempurna sehingga menghasilkan akumulasi yaitu oksidatif stress dan menjadi salah satu pemeran utama dalam perkembangan penyakit kronis dan degeneratif [2]. Untuk menjaga kondisi tubuh tersebut dibutuhkan asupan antioksidan dari luar seperti dari makanan.

Antioksidan adalah suatu zat yang dapat menangkal pengaruh buruk dari radikal bebas [3]. Salah satu jenis antioksidan yaitu antioksidan eksogen yang berasal dari makanan [2]. Antioksidan pada makanan berasal dari tanaman yang berpotensi untuk menstabilkan senyawa radikal yang dapat diukur dari aktivitas antioksidannya [4]. Aktivitas antioksidan adalah suatu istilah untuk menggambarkan kemampuan antioksidan dalam menghambat reaktivitas radikal bebas [5]. Salah satu makanan sumber antioksidan adalah beras coklat (Brown Rice) [6].

Beras coklat (Brown Rice) atau beras pecah kulit adalah beras yang hanya dihilangkan sekamnya, namun tidak dipoles menjadi beras putih. Beras pecah kulit mengandung protein, lemak, vitamin, mineral, serat dan antioksidan lebih banyak daripada beras putih [7]. Hasil penelitian menunjukkan bahwa rata-rata aktivitas antioksidan beras coklat sebesar 86,33\% [6]. Secara konvensional, metabolit sekunder dapat diperoleh dari ekstraksi langsung dari organ tanaman, namun jika dilakukan terus menerus berpengaruh terhadap ketersediaan spesies ta- naman serta dibutuhkan budidaya tanaman skala besar yang berdampak pada biaya yang besar pula. Oleh karena itu perlu adanya metode alternatif untuk meningkatkan senyawa bioaktif dalam tanaman salah satu cara adalah dengan elisitasi dan perkecambahan [8].

Elisitasi adalah metode untuk menginduksi pembentukan senyawa sekunder termasuk antioksidan dengan menambahkan senyawa yang disebut elisitor. Senyawa yang biasanya ditambahkan adalah polisakarida. Elisitasi bertujuan meningkatkan nilai gizi, aktivitas antioksidan dan dilakukan pada saat perendaman biji yang akan dikecambahkan [9,10]. Lama elisitasi mempengaruhi aktivitas antioksidan pada suatu bahan. Hasil penelitian Indriani menunjukkan bahwa lama elisitasi 2,4,6,8,10 jam berpengaruh terhadap aktivitas antioksidan kecambah kedelai, dimana waktu efektif peningkatan aktivitas antioksidan yaitu 2 jam dengan konsentrasi elisitor kitosan 500 ppm [11].

Perkecambahan adalah suatu proses tumbuhnya tanaman baru dari lembaga disertai adanya mobilisasi cadangan makanan dari jaringan penyimpanan atau keping biji ke bagian vegetatif (lembaga) [12]. Perubahan yang terjadi saat perkecambahan meliputi perubahan fisik dan kimia karena adanya aktifitas metabolism [13]. Selama perkecambahan terjadi aktivitasi enzim hidrolytic, polisakarida non-pati dan protein yang dapat menyebabkan terjadinya peningkatan komponen gizi seperti vitamin $\mathrm{C}$, protein, asam amino serta menghasilkan senyawa antioksidan baru seperti gamma-aminobutyric acid (GABA), gamma oryzanol, fenolik dan asam amino yang dapat meningkatkan aktivitas antioksidan [14,15]. Hasil penelitian Diniyah menunjukkan bahwa terdapat perbedaan nyata antara beras pecah kulit varietas IR-64 tanpa 
dikecambahkan dan dikecambahkan masingmasing sebesar $86,33 \%$ menjadi $90,04 \%$ [6].

Berdasarkan uraian diatas masih belum banyak penelitian mengenai penambahan elisitor pada proses perkecambahan terutama beras sehingga peneliti tertarik ingin mengetahui perbedaa lama elisitasi menggunakan elisitor kitosan dan perkecambahan terhadap aktivitas antioksidan kecambah beras coklat, sehingga dapat meningkatkan aktivitas antioksidan pada beras coklat yang dapat digunakan sebagai alternatif pangan sumber antioksidan.

\section{METODE PENELITIAN}

\section{Rancangan Penelitian}

Penelitian ini merupakan penelitian eksperimental dengan menggunakan Rancangan Acak Kelompok (RAK) yang disusun dengan dua faktor. Faktor pertama yaitu lama elisitasi dan faktor kedua lama perkecambahan yang terdiri dari enam perlakuan yaitu 12 jam eisitasi 24 jam perkecambahan, 18 jam eisitasi 24 jam perkecambahan, 24 jam eisitasi 24 jam perkecambahan, 12 jam eisitasi 36 jam perkecambahan, 18 jam eisitasi 36 jam perkecambahan, dan 24 jam eisitasi 36 jam perkecambahan dan diulang sebanyak tiga kali.

\section{Sasaran Penelitian}

Sampel yang digunakan dalam penelitian ini adalah beras coklat organik varietas Mentik yang sudah memenuhi kriteria inklusi yang didapat dari usaha penyelepan beras di Kecamatan Kedungkandang, Kota Malang. Bahan lain yang digunakan adalah elisitor kitosan (sebagai elisitor terbaik pada penelitian pendahuluan) dan pelarut metanol yang didapat dari toko Makmur Sejati Malang.

Prosedur pertama yang dilakukan adalah melakukan elisitasi. Kitosan ditimbang sebanyak $0,01 \mathrm{~g}$ kemudian dilarutkan dengan aquades sebanyak $100 \mathrm{ml}$. Timbang juga sampel beras coklat sebanyak $5 \mathrm{~g}$. Masukan beras yang telah di timbang pada wadah yang terpisah kemudian dilakukan pencucian sekali menggunakan air mengalir. Beras yang telah dicuci kemudian dilakukan perendaman dengan elisitor kitosan sebanyak $20 \mathrm{ml}$. Perendaman dilakukan dengan beberapa waktu yaitu selama 12 jam, 18 jam, dan 24 jam. Setelah proses perendaman, beras dicuci menggunakan air mengalir untuk menghilang- kan sisa elisitor. Pencucian ini diulang sebanyak $2 x$. Proses pencucian ini bertujuan untuk menghilangkan sisa elisitor yang masih menempel pada biji beras coklat, sehingga tidak mengundang datangnya mikroba yang dapat menyebabkan biji busuk sehingga gagal berkecambah. Selanjutkan beras coklat dihamparkan pada kassa steril untuk proses perkecambahan [16].

Selanjutnya adalah proses perkecambahan menggunakan dua waktu berbeda yaitu selama 24 jam dan 36 jam. Selama proses perkecambahan dilakukan penyemprotan pada beras coklat dengan rentang 1-3 jam sekali untuk memastikan beras tidak kering dan dapat berkecambah dengan baik. Setelah proses perkecambahan selesai kemudian beras coklat ditumbuk sampai halus sebelum dilakukan analisis laboratorium untuk mengetahui apakah ada perbedaan aktivitas antioksidan dengan variabel lama perendaman dan perkecambahan yang berbeda [16].

Pengujian aktivitas antioksidan dilakukan dengan metode DPPH (1,1-Diphenylpycryl-hydracil). Pertama sampel kecambah beras coklat dihaluskan dengan menggunakan mortar sampai halus. Dilakukan pengenceran sampel sebanyak 0,1 sampel dalam $10 \mathrm{ml}$ pelarut metanol. Sampel disaring dengan kertas saring halus kemudian diambil $2 \mathrm{ml}$ menggunakan mikropipet dimasukkan dalam tabung reaksi dan ditambahkan reagen DPPH sebanyak $1 \mathrm{ml}$ kemudian divortex hingga homogen. Selanjutnya didiamkan selama 30 menit pada suhu ruang $\left(25-27^{\circ} \mathrm{C}\right)$ dan kedap cahaya. Diukur absorbansi menggunakan spektrofotometri pada panjang gelombang 517 $\mathrm{nm}$ dan dihitung aktivitas antioksidan [17]. Variabel dependent adalah aktivitas antioksidan dan variable independen adalah lama elisitasi dan perkecambahan.

\section{Teknik analisis data}

Data hasil penelitian dianalisis normalitas dan homogenitasnya menggunakan uji Saphiro-Wilk dan kemudian dianalisis keragamannya menggukan uji ANOVA $(\alpha=0,05)$ dan apabila ada perbedaan antar perlakuan dilanjutkan dengan uji Post Hoc Tukey.

\section{HASIL PENELITIAN \\ Karakteristik Bahan Baku}

Beras yang digunakan dalam penelitian ini adalah beras coklat varietas mentik yang 
diperoleh dari petani beras organik di Malang. Pemilihan beras coklat dengan varietas mentik dikarenakan kandungan aktivitas antioksidan pada beras mentik lebih tinggi dibandingkan dengan varietas lain. Hasil penelitian Hartati dkk menunjukkan bahwa ekstrak hidrofilik bekatul menthikwangi memiliki aktivitas antioksidan dan total fenol tertinggi yaitu sebesar 41,30\% dan 2794,28 $\mu \mathrm{g}$ EAG/g di antara varietas beras yang lain seperti rajalele, IR-64 dan sintanur [8].

\section{Kitosan}

Elisitor yang digunakan dalam penelitian ini adalah elisitor kitosan yang merupakan elisitor terbaik dalam meningkatkan aktivitas antioksidan pada penelitian pendahuluan, apabila dibandingkan dengan elisitor alginate dan gum arab [18]. Kitosan dalam penelitian ini didapatkan dari toko Makmur Sejati Malang.

\section{Perkecambahan Beras Coklat}

Proses perkecambahan adalah serangkaian proses yang kompleks dan terjadi perubahan pada biji yang dikecambahkan seperti perubahan morfologi, fisiologi dan biokimia. Perubahan morfologi yang terjadi pada biji beras adalah munculnya embrio ke permukaan endosperm luar dan menembus kulit biji terluar yang keras. Proses perubahan morfologi dan biokimia yang terjadi selama perkecambahan diantaranya imbibisi, pengaktifan enzim dan hormon, proses perombakan cadangan makanan, pertumbuhan awal embrio [9]. Perbedaan hasil dari enam perlakuan penelitian perkecambahan dapat dilihat pada Gambar 1.

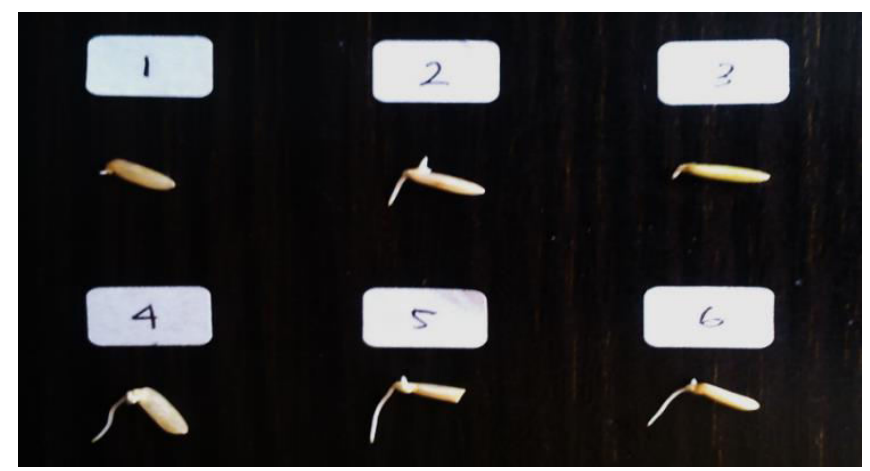

Keterangan: 1)12 jam elisitasi 24 jam perkecambahan, 2) 18 jam elisitasi 24 jam perkecambahan, 3) 24 jam elisitasi 24 jam perkecambahan, 4) 12 jam elisitasi 36 jam perkecambahan, 5) 18 jam elisitasi 36 jam perkecambahan, 6) 24 jam elisitasi 36 jam perkecambahan

\section{Gambar 1. Proses Perkecambahan Biji Beras}

Gambar 1 menunjukkan bahwa semakin lama perkecambahan, semakin panjang kecambah yang muncul pada biji beras coklat. Perkecambahan adalah proses pertumbuhan biji pada embryonic axis atau pembesaran sel yang sudah ada dan pertumbuhan sel baru yang diakibatkan karena terjadinya pembelahan sel [16].

\section{Aktivitas Antioksidan Kecambah Beras Coklat}

Rata-rata persentase aktivitas antioksidan pada kecambah beras coklat dengan variasi lama perendaman dan perkecambahan berkisar antara 11,68-15$91 \%$. Perbedaan lama perendaman dan perkecambahan terhadap aktivitas antioksidan kecambah beras coklat ditunjukkan pada Gambar 4.

Gambar 4 menunjukkan bahwa terdapat perbedaan aktivitas antioksidan pada semua perlakuan. Perbedaan signifikan yaitu pada perlakuan 18 jam elisitasi 24 jam perkecambahan dan perlakuan 24 jam elisitasi 24 jam perkecambahan dengan aktivitas antioksidan tertinggi pada perlakuan 24 jam elisitasi 24 jam perkecambahan sebesar $15,91 \%$.

\section{Analisis Data}

Analisis data hasil penelitian ini menggunakan uji ANOVA yang bertujuan 
untuk mengetahui perbedaan aktivitas antioksidan kecambah beras coklat berdasarkan lama elisitasi dan perkecambahan. Uji statistik pertama dilakukan adalah uji normalitas dengan menggunakan uji Shapiro-Wilk karena sampel kurang dari 30. Data dikatakan terdistribusi normal apabila nilai $p>0,05$. Hasil uji normalitas aktivitas antioksidan didapatkan bahwa data terdistribusi normal dengan nilai $\mathrm{p}=0,323 \quad(p>0,05)$, sehingga syarat pertama terpenuhi. Selanjutnya sebelum dilakukan pengujian menggunakan uji ANOVA, data diuji homogenitasnya. Data dikatakan homogen apabila nilai $p>0,05$. Hasil analisis menunjukkan bahwa data adalah homogen dengan nilai nilai $p=0,07$ $(p>0,05)$, sehingga kedua syarat untuk menggunakan uji ANOVA sudah terpenuhi. Berdasarkan hasil uji ANOVA didapatkan nilai $p=0,029 \quad(p<0,05)$ yang berarti terdapat perbedaan aktivitas antioksidan pada semua kelompok perlakuan. Untuk mengetahui kelompok perlakuan yang berbeda, dilanjutkan dengan uji Post Hoc. Perbedaan signifikan terdapat pada kelompok perlakuan 18 jam elisitasi 24 jam perkecambahan dan perlakuan 24 jam elisitasi 24 jam perkecambahan dengan aktivitas antioksidan tertinggi pada perlakuan 24 jam elisitasi 24 jam perkecambahan sebesar $15,91 \%$.

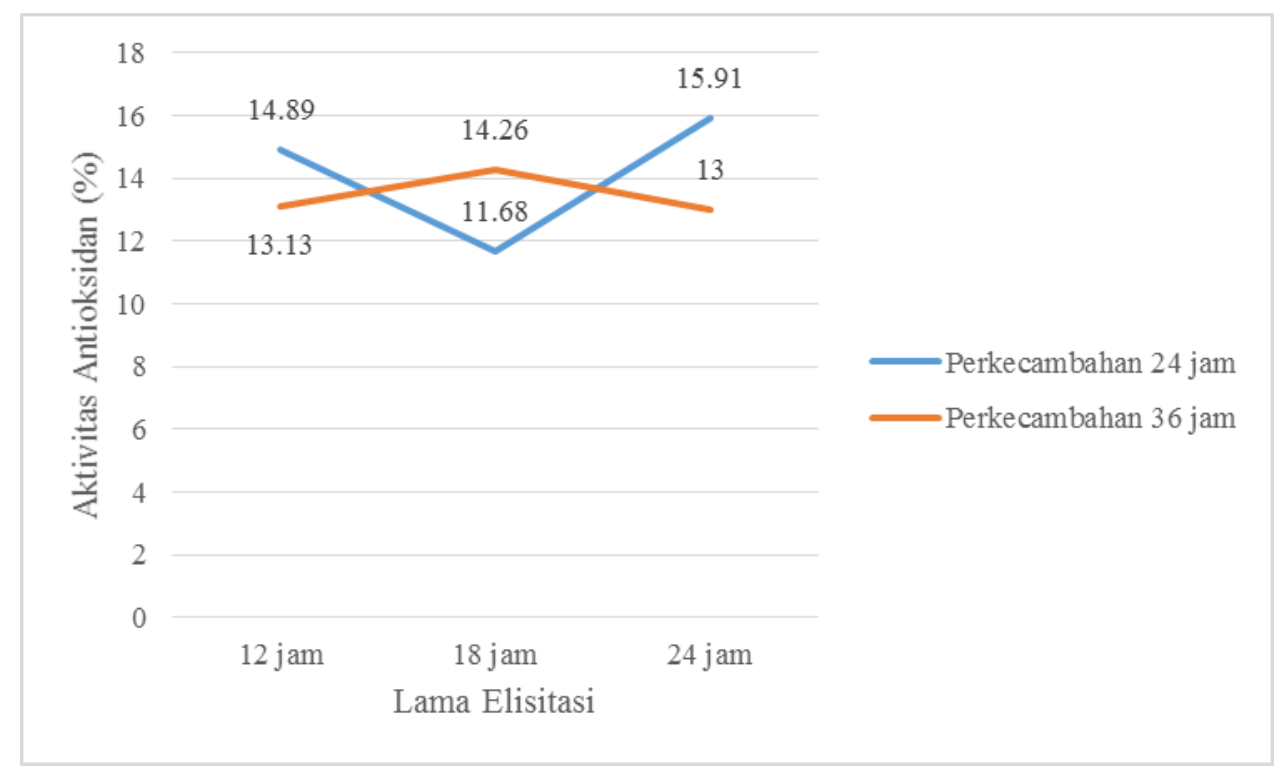

\section{Gambar 4. Perbedaan Lama Elisitasi dan Perkecambahan Terhadap Aktivitas Antioksidan (\% Inhibisi) Kecambah Beras Coklat}

\section{PEMBAHASAN}

\section{Perbedaan Aktivitas Antioksidan Ke- cambah Beras Coklat Berdasarkan Lama Elisitasi dan Perkecambahan}

Berdasarkan hasil yang telah didapatkan bahwa terdapat aktivitas antioksidan kecambah beras coklat berdasarkan lama elisitasi dan perkecambahan pada semua perlakuan. Perlakuan yang berpengaruh signifikan adalah perlakuan 24 jam elisitasi 24 jam perkecambahan dan
18 jam elisitasi 24 jam perkecambahan, dengan perlakuan terbaik pada kelompok 24 jam elisitasi 24 jam perkecambahan dengan akivitas antioksidan sebesar 15,91\%. Hasil tersebut lebih kecil bila dibandingkan dengan perkecambahan beras coklat atau beras pecah kulit varietas IR64 yang dilakukan oleh Diniyah dimana beras tanpa perkecambahan memiliki aktivitas antioksidan sebesar 86,33\% dan dengan perkecambahan sebesar 90,03\% 
[9]. Perbedaan tersebut dapat terjadi karena konsentrasi DPPH yang digunakan berbeda. Pada penelitian ini konsentrasi DPPH yang digunakan adalah $1 \mathrm{~mL}$, sedangkan penelitian Diniyah menggunakan konsentrasi $2 \mathrm{~mL}$. Besarnya konsentrasi senyawa antioksidan dalam reagen DPPH sangat berpengaruh terhadap aktivitas antioksidan yang dihasilkan [9].

Hasil dalam penelitian ini didapatkan trend bahwa semakin lama perendaman atau elisitasi semakin menurunkan aktivitas antioksidan yang terkandung dalam kecambah beras coklat. Menurut Indriani, bahwa semakin lama perendaman akan menurunkan zat gizi disebabkan lepasnya struktur dari zat gizi tersebut sehingga zat gizi akan terlarut dalam air seperti pati, vitamin, mineral, dan komponen lainnya [11]. Proses perendaman juga mengakibatkan terjadinya perubahan biologi yang dapat menyebabkan pecahnya berbagai komponen menjadi senyawa yang lebih sederhana. Namun pada perlakuan 24 jam elisitasi 24 jam perkecambahan mengalami peningkatan aktivitas antioksidan. Hal tersebut dapat disebabkan oleh perbedaan waktu optimal dalam pembentukan metabolit sekunder pada kecambah beras coklat. Elisitor dalam kelompok yang sama belum tentu memiliki kemampuan yang sama juga sebagai elisitor yang aktif [11]. Data mengenai lamanya waktu perendaman dengan elisitor masih belum banyak tersedia. Pembentukan metabolit sekunder diawali dengan peningkatan aktivitas enzim. Waktu preinkubasi yang terlalu lama dapat menyebabkan stress pada tanaman dan memungkinkan sel tanaman akan kehilangan kompetensi selama elisitasi, sedangkan elisitasi yang terlalu singkat menyebabkan pembentukan metabolit sekunder tanamanan tidak maksimal [11].

Setelah biji terelisitasi, maka proses selanjutnya adalah perkecambahan. Selama proses perkecambahan, biji beras akan mengenali elisitor sebagai senyawa asing yang kemudian biji akan menghasilkan fitoaleksin sebagai pertahanan terhadap elisitor tersebut [16]. Perkecambahan merupakan proses pengaktifan kembali aktivitas dalam biji yang terhenti yang kemudian membentuk bibit [9]. Perkecambahan dapat meningkatkan nilai gizi pada beberapa varietas biji yang dikecambahkan. Menurut Lee et al bahwa proses perkecambahan dapat meningkatkan aktivitas antioksidan pada semua kultivar gabah dikarenakan adanya sintesis dari senyawasenyawa yang memiliki sifat antioksidan selama proses perkecambaan berlangsung [14]. Hasil penelitian Diniyah bahwa aktivitas antioksidan beras pecah kulit yang dikecambahkan lebih tinggi daripada beras pecah kulit yang tidak dikecambahkan dengan peningkatan 34,23 kali lebih besar [6].

Hasil rata-rata aktivitas antioksidan dengan lama perkecambahan selama 24 jam lebih tinggi dibandingkan dengan perkecambahan 36 jam. Hal tersebut terkait dengan waktu optimal pembentukan antioksidan, dan perlakuan elisitasi karena dengan adanya perlakuan elsitasi sebelumnya maka metabolisme sel akan mengalami perubahan karena faktor stress yang ditambahkan [11]. Selain itu hasil penelitian Pike et al dalam Diniyah menyatakan bahwa semakin singkat durasi atau lama perkecambahan dapat meningkatkan aktivitas antioksidan [6]. Aktivitas antioksidan pada kecambah dipengaruhi beberapa komponen diantaranya adalah senyawa fenol dan adanya senyawa antioksidan baru seperti gamma-aminobutyric acid (GABA), gamma oryzanol, dan asam amino yang dapat meningkatkan aktivitas antioksidan. Peningkatan senyawa fenolik dalam biji yang dikecambahkan selalu diiringi dengan peningkatan aktivitas antioksidannya $[14,15]$.

Tingginya aktivitas antioksidan pada 24 jam perkecambahan disebabkan adanya berbagai mekanisme yang terlibat seperti pembentukan ROS atau radikal bebas yang lebih tinggi, perubahan aliran ion pada mambran sel, reaksi hipersensitif dan 
pada akhirnya teraktifasinya pembentukan metabolit sekunder sebagai sistem pertahanan tanaman [11]. Adanya stress oksidatif dalam sel tanaman membuat tanaman menyesuaikan kondisi dalam sel dengan melakukan pembentukan dan peningkatan sistem pertahanan untuk menghindari kerusakan pada sel yaitu dengan cara pembentukan metabolit sekunder salah satunya adalah antioksidan [19]. Pada perkecambahan 36 jam mengalami penurunan dapat disebabkan oleh adanya efek post binding yang terjadi antara reseptor dan elisitor. Hal tersebut sesuai dengan penelitian Indriani dimana terjadi peningkatan aktivitas antioksidan pada perkecambahan kacang kedelai hitam dengan waktu perkecambahan 72 jam dengan menggunakan elisitor kitosan dan mengalami penurunan pada perkecambahan 96 jam [11]. Efek post binding dapat terjadi karena adanya perbedaan kecepatan kemampuan sel dalam merespon suatu sinyal elisitor. Hal ini sesuai dengan Hasil penelitian Yuni dimana lama perkecambahan berpengaruh terhadap penurunan aktivitas antioksidan kecambah beras pada tiga kultivar padi lokal [20].

\section{Implikasi Terhadap Bidang Gizi Kesehatan}

Kecambah beras coklat atau disebut Germinated Brown Rice merupakan kecambah beras yang tumbuh secara alami pada suhu dan kelembapan yang tepat sehingga dapat meningkatkan kandungan gizi yang baik untuk tubuh. Tim peneliti Jepang mengungkapkan bahwa beras pecah kulit yang dikecambahkan memiliki nilai gizi lebih dibandingkan beras pecah kulit tanpa dikecambahkan [9].

Dalam penelitian ini hasil terbaik adalah pada perlakuan 24 jam elisitasi 24 jam perkecambahan yaitu sebesar 15,91\% yang menunjukkan kadar antioksidan pada kecambah beras coklat serta kemampuannya dalam menangkal radikal bebas. Konsumsi kecambah beras coklat $100 \mathrm{~g} /$ hari dapat bermanfaat untuk meningkatkan kualitas kesehatan, meningkatkan sistem kekebalan tubuh, menurunkan tekanan darah, menghambat perkembangan sel-sel kanker, dan membantu pengobatan gangguan kecemasan menstimulasi pelepasan insulin pada diabetes tipe 2, serta memperbaiki fungsi ginjal. Hal tersebut terkait dengan kandungan gizi pada kecambah beras coklat seperti gamma-aminobutyric acid (GABA) sebesar $92.42 \mathrm{mg} / 100 \mathrm{~g}$, serat 3,7 g/100 g, kandungan asam amino essensial Lysine dan amilosa yang rendah (Ningrum, 2009 ; Seki et al., 2005 ; Patil and Khan, 2011 ; Ard and Songsrempong, 2012) $[9,21,22,23]$.

Penelitian lain menunjukkan bahwa mengonsumsi kecambah beras coklat selama 5 minggu dapat menurunkan secara signifikan hingga $23 \%, 31 \%$, dan $45 \%$ tingkat glikemia, kolesterol total dan LDL pada tikus yang diabetes. Selain itu terjadi peningkatan HDL sebesar $45 \%$. Hal ini berkorelasi dengan kandungan amilosa yang rendah pada kecambah beras coklat yang mempengaruhi glikemia dan profil lipid penderita diabetes [24]. Kandungan serat dalam kecambah beras coklat dapat menurunkan indeks glikemik melalui pengaturan penyerapan glukosa dalam usus [25].

\section{SIMPULAN}

Berdasarkan hasil penelitian, dapat disimpulkan bahwa terdapat perbedaan aktivitas antioksidan kecambah beras coklat berdasarkan lama elisitasi dan perkecambahan. Aktivitas antioksidan kecambah beras coklat pada berbagai perlakuan yaitu 12 jam elisitasi dan 24 jam perkecambahan yaitu sebesar 14,89\%, perlakuan 18 jam elisitasi dan 24 jam perkecambahan sebesar $11,68 \%$, perlakuan 24 jam elisitasi 24 jam perkecambahan sebesar $15,91 \%$, perlakuan 12 jam elisitasi 36 jam perkecambahan sebesar $13,13 \%$, perlakuan 18 jam elisitasi 36 jam perkecambahan sebesar $14,26 \%$, dan perlakuan 24 jam elisitasi 36 jam perkecambahan yaitu sebesar 13\%. Aktivitas antioksidan 
terbaik yaitu pada perlakuan 24 jam elisitasi 24 jam perkecambahan yaitu sebesar $15,91 \%$. Dari hasil penelitian tersebut maka kecambah beras coklat dapat direkomendasikan kepada masyarakat untuk dikonsumsi sebagai bahan pangan sumber antioksidan.

\section{DAFTAR RUJUKAN}

1. Benazir. 2011. Tingkat Pengetahuan Mahasiswa Fakultas Kedokteran USU Tentang Pengaruh Radikal Bebas Terhadap Timbulnya Penyakit. Universitas Sumatra Utara.

2. Pham-Huy, L.A., He, H, and PhamHuy, C. 2008. Free Radicals, Antioxidants in Disease and Health. http://www.ncbi.nlm.nih.gov/pmc/arti cles/PMC3614697/pdf/IJBS-4-89.pdf diakses pada 26 Mei 2015

3. Angela, L. 2012. Aktivitas Antioksidan dan Stabilitas Fisik Gel Anti-Aging Yang Mengandung Ekstrak Air Kentang Kuning (Solanum tuberosum L). Fakultas Matematika dan Ilmu Pengetahuan Alam Program Ekstensi Departemen Farmasi Universitas Indonesia.

4. Panjaitan, T.D., Prasetyo, B, dan Limantara, L. 2010. Peranan Karotenoid Alami Dalam Menangkal Radikal Bebas di dalam Tubuh. Program Magister Biologi, Universitas Kristen Satya Wacana.

5. Winarsi, H. 2007. Antioksidan Alami dan Radikal. Kanisius : Yogyakarta

6. Diniyah, E. 2009. Optimasi Jenis Pelarut Untuk Ekstraksi Antioksidan Alami Dari Fraksi-Fraksi Gabah (Oryza Sativa L. Kultivar. IR64) serta Aplikasi Perkecambahan Dan Gelombang Mikro Untuk Pengingkatan Antioksidan. Skripsi. Jurusan Teknologi Hasil Pertanian Fakultas Teknologi Pertanian Universitas Brawijaya.

7. Zakaria, F.R. 2004. Beras Sosoh Sebagian (Halfpolished Organic Rice). Departemen llmu dan
Teknologi Pangan Institut Pertanian Bogor.

8. Hartati, S, Marsono, Y, Suparno, dan Santoso, U. 2015. Komposisi Kimia Serta Aktivitas Antioksidan Ekstrak Hidrofilik Bekatul Beberapa Varietas Padi. Agritech. Vol 35, No 1.

9. Ningrum, D.C. 2009. Pengkajian Proses Pembuatan Tepung GBR (Germinated Brown Rice) Kombinasi Antara Lama Perkecambahan Gabah Dan Sistem Pengeringan. Skripsi. Jurusan Teknik Pertanian Fakultas Teknologi Pertanian Universitas Brawijaya

10. Purwianingsih, W, dan Hamdiyati, Y, 2009. Metode Elisitasi Menggunakan Ragi Sacharomyces cerevisiae H. untuk Meningkatkan Kandungan Bioaktif Kuinon Kalus Morinda citrifolia L. (Mengkudu). Skripsi Prodi Biologi Jurusan Pendidikan Biologi FPMIPA Universitas Pendidikan Indonesia.

11. Indriani, C. 2015. Pengaruh Penggunaan Elisitor Polisakarida Terhadap Aktivitas Antioksidan Kecambah Kedelai Hitam. Skripsi. Jurusan Fakultas Hasil Pertanian Fakultas Teknologi Pertanian Universitas Brawijaya.

12. Anggraeni. 2003. Pengaruh Penggunaan Polisakarida Sebagai Elisitor untuk Produksi Antioksidan Selama Germinasi Biji Kacang Hijau (Phaseolus radiates, Linn). Fakultas Teknologi Pertanian Institut Pertanian Bogor.

13. Kementrian Kehutanan, 2012. Perkecambahan Benih. Direktorat Jenderal Bina Pengelolaan Daerah Aliran Sungai Dan Perhutanan Sosial Balai Perbenihan Tanaman Hutan Sulawesi.

14. Lee, Y.R., Woo, K.S., Kim, K.J., Son, J.R., and Jeong, H.S. 2007. Antioxidant Activities Of Ethanol Extracts From Germinated Specialty Rought Rice. Food Science 
Biotechnology. Vol.16 No 5: 765770.

15. Pertiwi, S.F., Aminah, S, dan Nurhidajah. 2013. Aktivitas Antioksidan, Karakteristik Kimia, dan Sifat Organoleptik Susu Kecambah Kedelai Hitam (Glycine Soja) Berdasarkan Variasi Waktu Perkecambahan. Jurnal Pangan dan Gizi. Vol.04 No.08.

16. Maligan, J.M dkk. 2017. Studi Aktivitas Antioksidan Kecambah Beras Coklat (Perlakuan Konsentrasi Elisitor Kitosan dan Lama Elisitasi). Rekapangan Vol 11 No.1: 22-28.

17. Pandie, S. F. 2007. Pembuatan Bubuk Ekstrak Kecambah Gandum Terelisitasi dengan Na-Alginat sebagai Sumber Antioksidan. Skripsi. Jurusan Teknologi Pertanian Universitas Brwaijaya Malang.

18. Maligan, J. M. dkk. 2017. Peranan Proses Elisitasi dan Perkecambahan untuk meningkatkan Aktivitas dan Kandungan Senyawa Bioaktif Beras Coklat. Prosiding Seminar Nasional Teknik Kimia UNPAR 2017 (B41B45).

19. Ningsih, I.Y. 2014. Pengaruh Elisitor Biotik Dan Abiotik Pada Produksi Flavonoid Melalui Kultur Jaringan Tanaman. Bagian Biologi Farmasi, Fakultas Farmasi Universitas Jember, Indonesia. Pharmacy. Vol.11 No. 02 Desember 2014 Issn 1693-3591

20. Zhao, J., davis, L.C., and Verpoorte, R. 2005. Elicitor Signal Transduction Leading Of Production Of Plant
Secondary Metabolites. Biotechnol. Adv.vol.23,283-333

21. Yuni, N. 2015. Analisis Kandungan Gamma-Aminobutyric Acid (GABA), Fenol Total, Dan Aktivitas Antioksidan Germinated Rice Tiga Kultivar Padi Lokal (Oriza Sativa L.) Yogyakarta.

22. Seki, T.R., Nagase, dan Torimitsu, M. 2005. Insoluble Fiber Is A Major Constituent Responsible For Lowering The Post-Prandial Blood Glucose Concentration In The PreGerminated Brown Rice. Biological And Pharmaceutical Bulletin. Vol 28, No. 8,Pp. 1539-1541.

23. Patil, S.B, and Khan, K. 2011. Germinated Brown Rice As A Value Added Rice Product. Journal of Food Science And Technology. Vol 48, Issue 6,PP 661-667 Http://Link.Springer.Com/Article/10. 1007\%2Fs13197-011-0232-4

24. Ard, T.K, and Songsermpong. S. 2012. Influence of germination time on the GABA content and physical properties of germinated brown rice. As. J. Food Ag-Ind. Vol 5(04), 270283

25. Shallan, M. A., Beltagi, H. S., Mona, A. M., Amera, T. M, and Sohir, N. A . 2010. Effect of Amylose Content And Pregerminated Brown Rice On Serum Blood Glucose And Lipids In Experimental Animal. Australian Journal Of Basic And Applied Sciences. Vol 4, No. 2, Pp. 114-121. 